\title{
The validation of hydrodynamic modelling for 2014 flood in Kuala Krai, Kelantan
}

\author{
Syaza Faiqah Maruti ${ }^{1}$, Shahabuddin Amerudin ${ }^{1 *}$, Wan Hazli Wan Kadir $^{1}$, and Zainab \\ Mohamed Yusof $^{2}$ \\ ${ }^{1}$ Faculty of Built Environment and Surveying, Universiti Teknologi Malaysia, 81310 Johor Bahru, \\ Malaysia \\ ${ }^{2}$ Faculty of Engineering, Universiti Teknologi Malaysia, 81310 Johor Bahru, Johor, Malaysia
}

\begin{abstract}
Flood catastrophe that struck Kelantan in 2014 has marked as the worst in history. The absence of structural approach such as dam has increased the risks of the flood to this state. In this paper, the simulation of 2014 flood event focuses in Kuala Krai area has been carried out before and after the occurrence of the proposed dams along Galas and Lebir rivers, respectively using hydrodynamic model. The Digital Terrain Model (DTM) from Airborne Light Detection and Ranging (LiDAR) combining with Shuttle Radar Topography Mission (SRTM) data resources have been used for hydrodynamic modelling. The flow hydrograph and water level are generated as input data for initial and boundary conditions. River crosssections and Manning's roughness coefficient values that been estimated based on landcover map obtained in 2010 also used in the model. The model produces the outputs of flood depth and velocity. To validate the simulation results, the flood depths were compared against the flood marks depth from field survey at 16 locations collected by researchers from Disaster Prevention Research Institute, Kyoto University, Japan and Department of Irrigation and Drainage (DID). From the validation, it reveals that the average accuracy percentage obtained was about $90 \%$ and it can be said that the flood model was acceptable.
\end{abstract}

\section{Introduction}

Flood catastrophes are the main natural hazard in Malaysia, numerous flood event have been recorded from 1926 until 2015 which cause major damages and deaths. One has to live with the flood disaster by reducing the impact since avoiding it is impossible [1]. There are 714 floods events have been recorded in 5 years between 2011 and 2015 which comprised of 556 events of flash flood, 147 events of monsoon flood, 4 events of mud flood, 7 flood events due to dam release and over than 200 flash floods have been occurred in 2015 on that occasion [2]. However, the extreme flood disaster occurred in 2014 particularly in the east coast part of Peninsular Malaysia has caused great loss of assets and

*Corresponding author: shahabuddin@utm.my 
lives. Kelantan was the most affected by flood as stated by The National Security Council, 2014 flood event was recorded as the worst in this state's flood historical [3]. The intense rainfalls occurred in December 2014 that cause a flood in Kelantan were influenced by multiple contributing factors [4]. The combination of the annual monsoon season and the global climatic patterns contribute to the rain enhancement. The severe flood event has awakened the importance of the presence of structural approach such as dam in reducing the risks of the flood to this state. However, the hydrodynamic modelling is necessary to be done for flood study before any structural is developed. Further, the feasibility of the dam in reducing flood hazard can be assessed [5]. Moreover, the potential damage and risk can be calculated plus uses by mean of the basis for environmental impact assessment for development project preposition several flood scenarios obtained from flood simulation [6]. In this study, the hydrodynamic modelling has been carried out to simulate the 2014 flood event with and without the occurrence of the proposed dams along Galas and Lebir rivers, respectively by using 1D2D SOBEK model. The study was focused in Kuala Krai area where the risk of flood hazards this area have been observed before and after the existence of the proposed dams. Then, the accuracy of the results obtained from the hydrodynamic model has been validated by comparing the simulated flood depth against the flood marks depth at 16 locations in Kuala Krai area obtained from field survey by [7] and [8].

\subsection{Study Area}

Kelantan state located at the northeast part of Peninsular Malaysia. It consists of several districts namely as Kota Bharu, Tumpat, Bachok, Pasir Mas, Tanah Merah, Machang, Pasir Putih, Kuala Krai and Gua Musang. The major water resource for this state is the Kelantan river. This river emerges at the confluence of the Galas and Lebir rivers near Kuala Krai before it transforms to broader stream with mud-colour. Then, it meanders over the coastal plain until it reached into the South China Sea which is about $12 \mathrm{~km}$ north of Kota Bharu. In this study, the proposed dams are located at the upstream are along the tributaries of Galas and Lebir rivers, respectively. The proposed Kemubu dam is located about $18 \mathrm{~km}$ upstream from the Kemubu railway bridge while the Lebir dam is at about $40 \mathrm{~km}$ upstream from the confluence with Galas river. Meanwhile, the flood been with and without the occurrence of the proposed dams were observed at the downstream area particularly at Kuala Krai. Kuala Krai area formed as a hilly land area. The catchment area is $2,329 \mathrm{~km}^{2}$ where it comprises about 104,356 of population recorded in 2010 with the density of 45 $\mathrm{km}^{2} /$ people. Figure 1 shows the area of study.

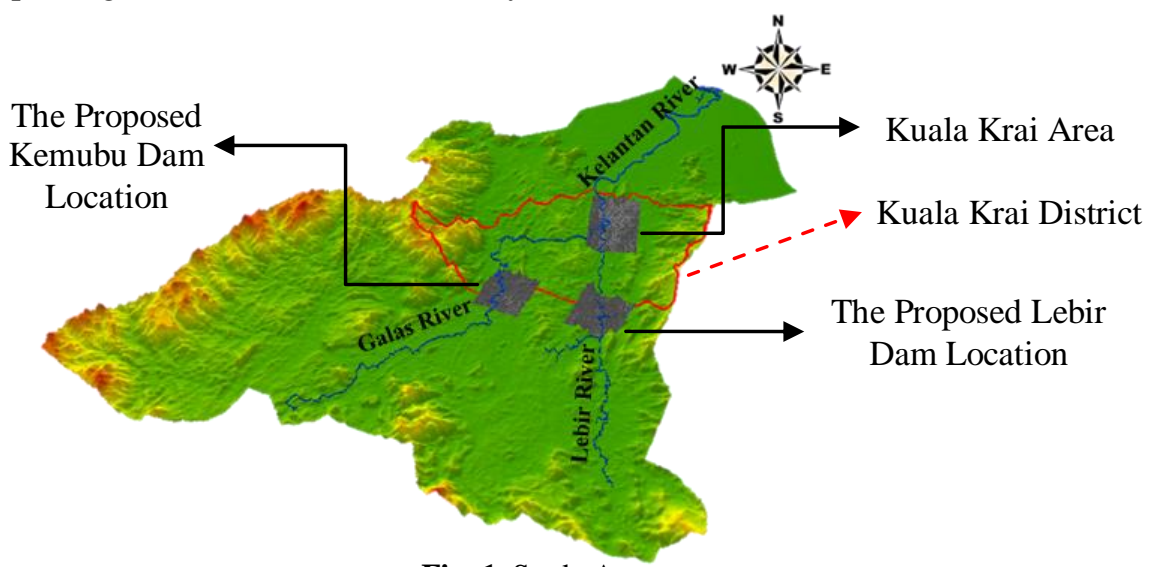

Fig. 1. Study Area 


\section{Material and Method}

The methodology of this study was divided into 5 phases which are i) data collection, ii) data pre-processing, iii) flood model schematization iv) flood simulation and v) validation. The first phase aims to collect the data such as DTM, landcover map, hydrological data, cross section and river networks data as well as information for dam specifications. Preprocessing responsible for preparing all the data input requires for flood modelling such as the generation of DTM from different remotely sensed data sources, resampling DTM resolution to $15 \mathrm{~m}$ spatial resolution and defining the proposed dams onto it and generating manning's $n$ surface roughness value. For flood model schematization, the data such as series of discharge and water level, cross section, river network and surface roughness value are required. Flood simulation includes the simulation of the proposed dams, respectively and the flood simulation of Kuala Krai before and after the occurrence of the proposed dams. In the final phase, the accuracy of flood depth based on the flood simulation results have been validated.

\subsection{Data Collection}

The DTM data used for flood modelling were combined from different data sources of Airborne LiDAR data with a spatial resolution of $3 \mathrm{~m}$ and STRM with a spatial resolution of $30 \mathrm{~m}$. The DTM is then resampled to $15 \mathrm{~m}$ of spatial resolution to cope with the SOBEK's hydrodynamic model limitation. The landcover map of the year 2010 obtained from the Ministry of Agriculture is used to generate the Manning's $n$ surface roughness value. The series water level and discharge data were obtained from the Department of Drainage and Irrigation (DID). Cross section and river network data also required purposely for the 1D computational model. Not only that, the information of the dam specifications also been identified through a literature review on Unit Perancang Ekonomi Negeri (UPEN) previous report [9].

\subsection{Data Pre-Processing}

\subsubsection{Generation of The Proposed Dams Onto DTM}

The proposed Kemubu and Lebir dams are formed by raising the DTM's pixel elevation through the information of dam specification retrieved in UPEN report. The proposed Lebir dam is located approximately at about $40 \mathrm{~km}$ upstream from the confluence with Galas river, while the proposed Kemubu dam is about $18 \mathrm{~km}$ upstream from the Kemubu railway bridge. Both dams were designed with three outlets as a spillway. The dam crest elevation is raised at $73 \mathrm{~m}$ and $85 \mathrm{~m}$, and spillway elevation at $63 \mathrm{~m}$ and $78 \mathrm{~m}$ for Kemubu and Lebir dams, respectively. In addition, the saddle dam was proposed about $2 \mathrm{~km}$ northeast of Lebir dam where the elevation of the DTM's pixel elevation has raised to $85 \mathrm{~m}$. The saddle dam intends to prevent the floods water from flowing to downstream. 


\subsubsection{Manning's Surface Roughness.}

In this study, the Manning's $n$ value is generated by converting each of the land use classes in the map [10]. The values were adjusted suitable to the surrounding of the study area, as shown in Table 1.

Table 1. A lookup table of $n$ value conversion.

\begin{tabular}{|l|c|}
\hline Landuse & Manning's $\boldsymbol{n}$ \\
\hline Built-up Area & 0.01 \\
\hline Cleared Land & 0.01 \\
\hline Rubber & 0.15 \\
\hline Forest & 0.3 \\
\hline Paddy & 0.2 \\
\hline Oil Palm & 0.25 \\
\hline Others Agriculture & 0.2 \\
\hline Water Bodies & 0.033 \\
\hline
\end{tabular}

\subsubsection{Series Discharge and Water Level for Initial And Boundary Condition}

In this study, the input for the inlet boundary condition was defined as the series of discharge meanwhile the outlet boundary is the series of the water level. The series of discharge and water level data obtained from DID are designated in hourly for initial and boundary conditions. For the proposed Kemubu dam, the series discharge and water level data were selected from "Sg. Nenggiri station at Jambatan Bertam". For the proposed Lebir dam, the hydrological data were selected from "Sg. Lebir station at Kg. Tualang" station. Further, the data during the wet season in December 2014 have been used to designate the series discharge and water level for boundary conditions. Meanwhile, the simulation of Kuala Krai have two inlet boundary which used the series of discharge from "Sg. Galas station at Bukit Apit Dabong" and "Sg. Lebir at Kg. Tualang" stations. Then, the outlet boundary used the water level that was taken from "Sg. Kelantan station at the Jambatan Guillermard/Kusial.

\subsection{Flood Model Schematization}

In schematize the flood model, the data such as series of discharge and water level, cross section, river network and surface roughness value that have been pre-processed are required. The river networks and cross sections are necessary to simulate the model. The river network is used as a reference to generate the reach in the model schematization. The cross sections in this study used survey data provided by a consultant in 2016 . However, the cross sections provided did not cover the whole study area for Kuala Krai, Nenggiri and Lebir rivers. Therefore, the cross sections for the rest of the study area were extracted from the DTM from LiDAR data source. 


\subsection{Flood Simulation}

Flood simulation of the proposed dams literally focuses at the upstream area along the Galas and Lebir rivers meanwhile the flood simulation of Kuala Krai focuses downstream area particularly in Kuala Krai area after the confluence of Galas and Lebir rivers. The simulation has been carried out using SOBEK hydrodynamic model that was developed by WL|Delft Hydraulic founded in 1927. SOBEK is a powerful flood forecasting model featuring an integrated 1D and 2D model [11]. The 1D model involves each computational point corresponding to a cross-section at the selected locations along river network, while the 2D model uses a finite difference method for computation of the floodplain, represented in grid cells.

\subsubsection{Simulation of the proposed dams}

The simulation of the proposed dams is initiated after the dams have been formed onto the DTM with specification by [9]. The designate hydrograph for flood simulation 2014 flood event designated directly according to the series discharge data of 2014 flood event obtained from DID. Figures 2 (a) and (b) below show the hydrograph that have been used as input data for inlet boundary at the proposed Kemubu and Lebir dams, respectively.

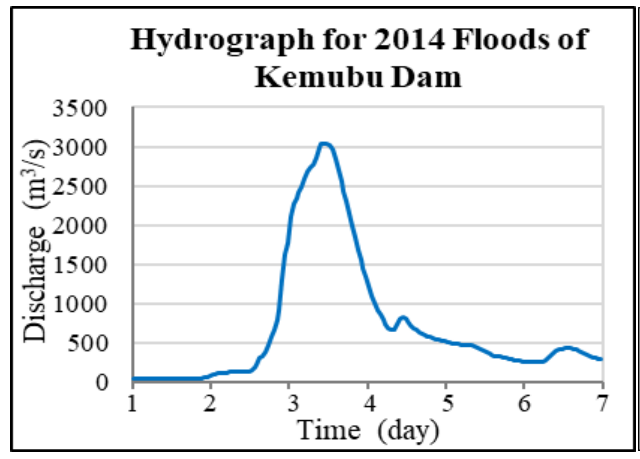

(a)

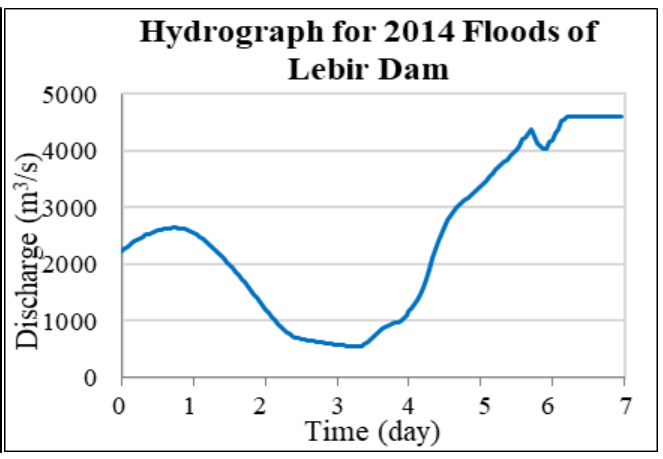

(b)

Fig. 2. Hydrograph used as input data for inlet boundary at the proposed; (a) Kemubu dam (b) Lebir dam

\subsubsection{Simulation of Kuala Krai without the occurrence of proposed dams}

The flood simulation of Kuala Krai without occurrence of proposed dams used two inputs from the series of discharge from Dabong and Lebir stations as inputs for inlet boundary condition. Meanwhile, the series of water level is used for outlet boundary condition from Kelantan Guillermard station. The hydrograph for the real event was also designed directly according to the discharge data that been measured on the date of 2014 flood event occurred obtained from DID. The hydrograph selected was from $17^{\text {th }}$ to $31^{\text {st }}$ December 2014. The hydrograph that have been used as input data for inlet boundary at Lebir and Dabong inlet are showed in Figure 3 (a) and (b), correspondingly. 


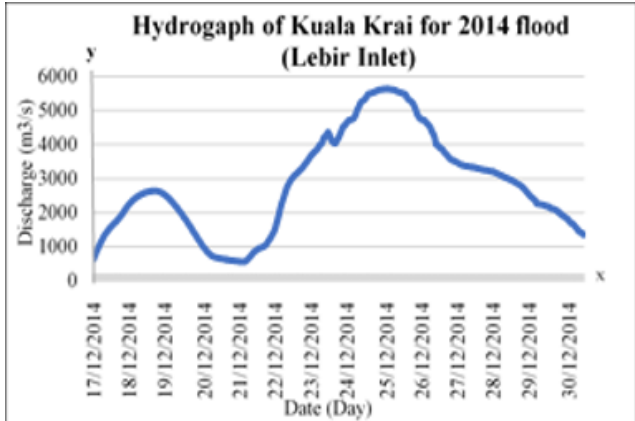

(a)

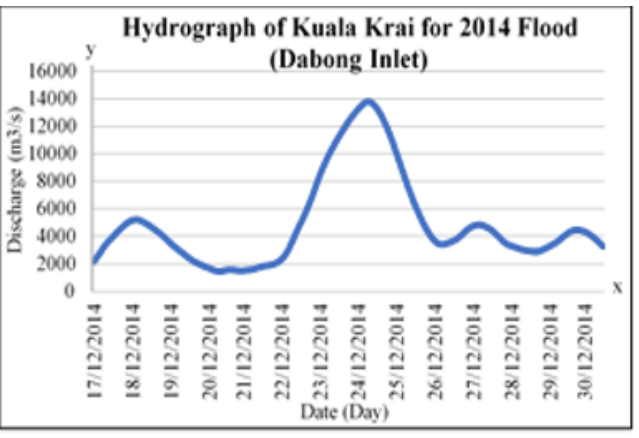

(b)

Fig. 3. Hydrograph used as input data for inlet boundary at; (a) Lebir inlet (b) Dabong inlet

\subsubsection{Simulation of Kuala Krai with the occurrence of proposed dams}

The flood simulation of Kuala Krai with the occurrence of the proposed dams is only initiated after the simulation of the proposed Kemubu and Lebir dams have been completely done. This is because, the discharge of the excessive flood water through the spillways that have been measured at the measurement station situated at the artificial river in SOBEK model schematization are used as inputs for boundary condition for this simulation. From the flood simulation of the proposed dams, the presence of the proposed Kemubu dam has reduce the excessive amount of flood waters contributed from the high flood magnitude. This occasion also has indirectly reduce the discharge of that exceeded water that flows to the downstream area. On the other hand, there are no discharge has been measured at the proposed Lebir dam.

\subsection{Validation}

From validation, the accuracy of the results obtained from hydrodynamics modelling can be verified. In this study, the validation has been done by comparing the flood depth obtained from flood simulation with the flood marks depth of the real event. Initially, the flood depths that have been obtained from flood simulation of Kuala Krai for 2014 flood event using 1D2D SOBEK model were compared to the flood marks depth at Kuala Krai town from field survey which was conducted from $2^{\text {nd }}$ until $4^{\text {th }}$ March 2015 by several researchers from Disaster Prevention Research Institute, Kyoto University, Japan [7] Nonetheless, the validation of flood depth has been strengthened by increase the number of points observed from field survey by [8] to be compared in order to improve the accuracy of this study. Figure 4 showed the field survey of the flood marks done by DID. The level of the flood marks depth has been taken from the ground elevation to the flood marks elevation using levelling rod. 


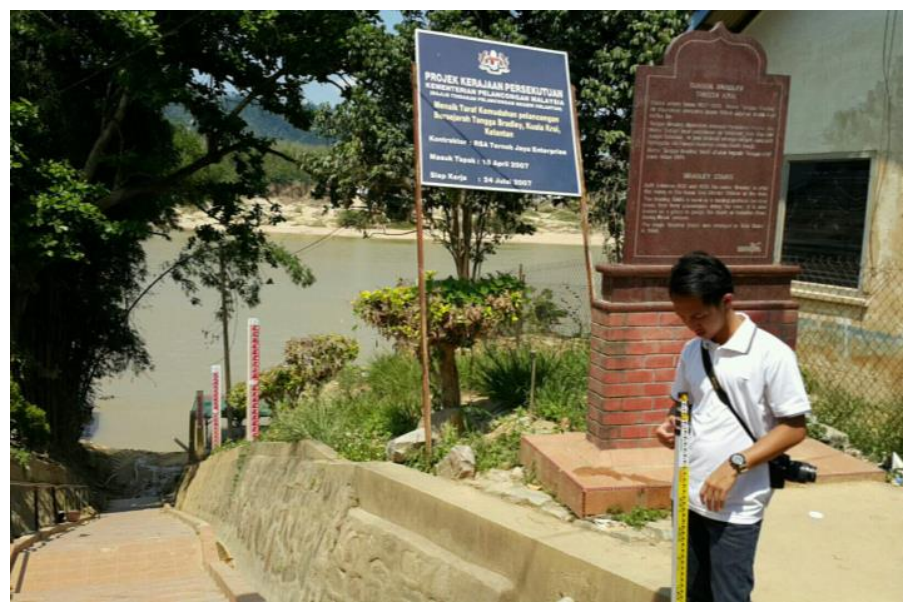

Fig. 4. Flood marks depth field surveyed by DID [7]

\section{Flood Simulation Results and Validation}

\subsection{Flood Scenarios of The Proposed Dams Simulation}

There are two output parameters obtained which are maximum velocity and maximum water depth. The maps of a maximum velocity and water depth are generated as shown in Figure 5 and 6. From the simulation of the proposed Kemubu and Lebir dams, the results of maximum velocity obtained for 2014 flood event flood modelling were $17.2 \mathrm{~m} / \mathrm{s}$ and 3.8 $\mathrm{m} / \mathrm{s}$, respectively meanwhile the maximum water depth were $38.1 \mathrm{~m}$ and $41.2 \mathrm{~m}$, respectively.

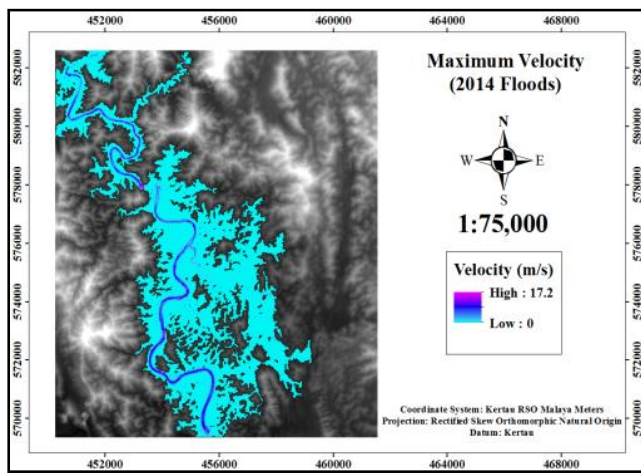

(a)

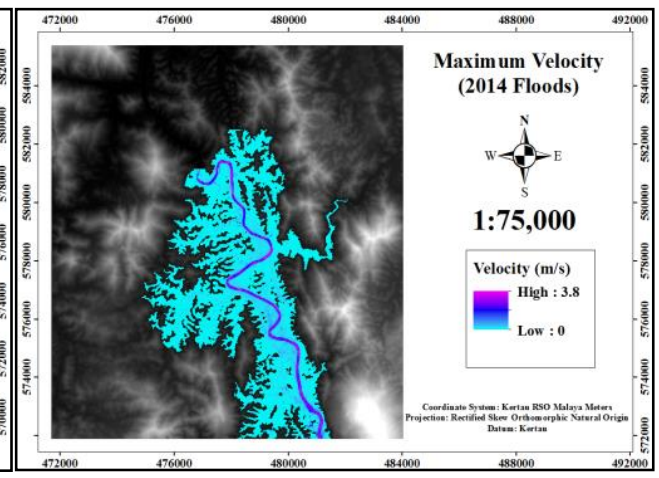

(b)

Fig. 5. Map of Maximum Velocity (a) The proposed Kemubu dam (b) The proposed Lebir dam 


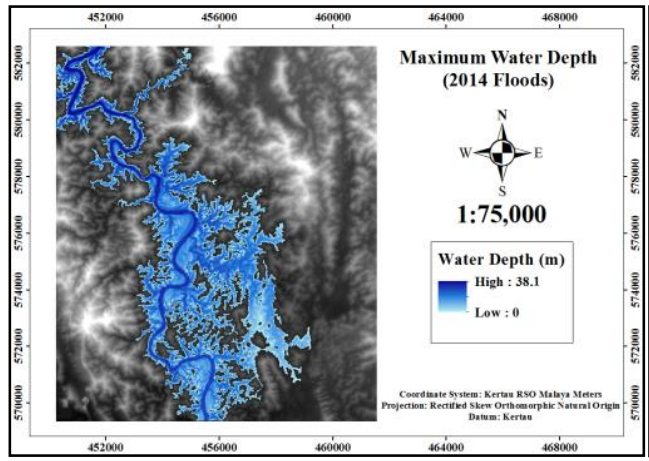

(a)

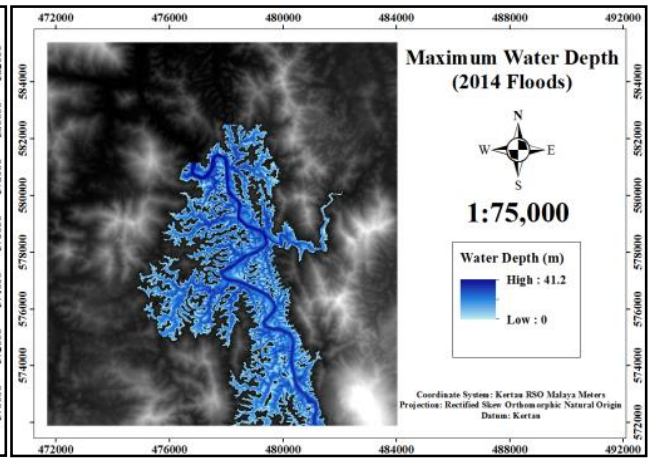

(b)

Fig. 6. Map of Maximum Water Depth (a) The proposed Kemubu dam (b) The proposed Lebir dam

\subsection{Flood Scenarios of Kuala Krai Without The Occurrence of Proposed Dams}

The maps of a maximum velocity and water depth of Kuala Krai without the proposed dams are generated as shown in Figure 7 (a) and (b). The results showed the maximum velocity of the 2014 flood was $34 \mathrm{~m} / \mathrm{s}$ while the maximum water depth was $19 \mathrm{~m}$. The flooded area of Kuala Krai was about $30 \mathrm{~km}^{2}$.

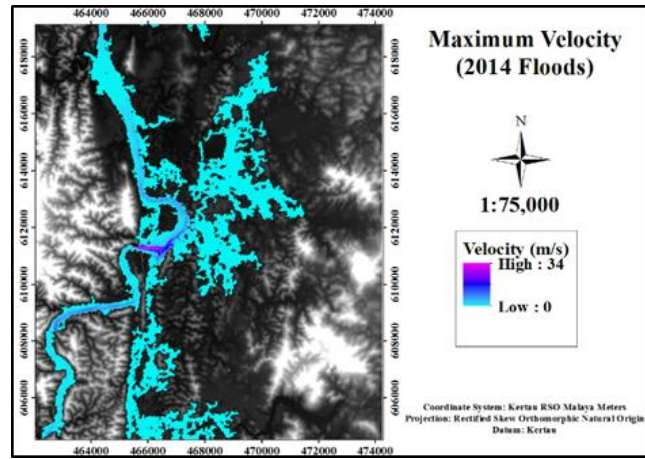

(a)

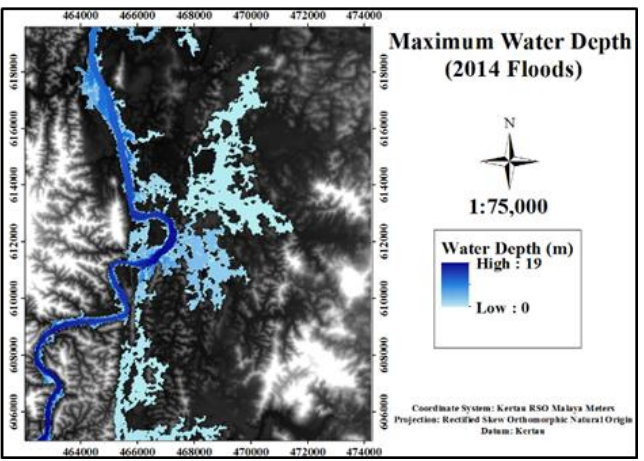

(b)

Fig. 7. Floodplain at Kuala Krai, a) a maximum velocity (b) a maximum water depth

\subsection{Flood Scenarios of Kuala Krai With The Occurrence of Proposed Dams}

The flood simulation of Kuala Krai with proposed dams showed that no flood occurred in Kuala Krai. The discharge after the dams measured from the simulation of the proposed Kemubu and Lebir were not sufficient to trigger the flood at the downstream area. From the flood simulation of the proposed Kemubu and Lebir dams, the discharge obtained at the proposed Kemubu dam with some discharge of the floodwater been measured. Nevertheless, the proposed Lebir dam occurrence have efficaciously in remain the floodwater to escape to the downstream area after the dam's spillways. Therefore, there is no discharge has been measured at the proposed Lebir dam. It can be seen that the peak discharge after the development of the Kemubu dam was decreased from $2956 \mathrm{~m}^{3} / \mathrm{s}$ to 142 
$\mathrm{m}^{3} / \mathrm{s}$, indicating the decrement was about 95 per cent. Figure 8 shows the discharge hydrograph before and after the development of the proposed Kemubu dam.

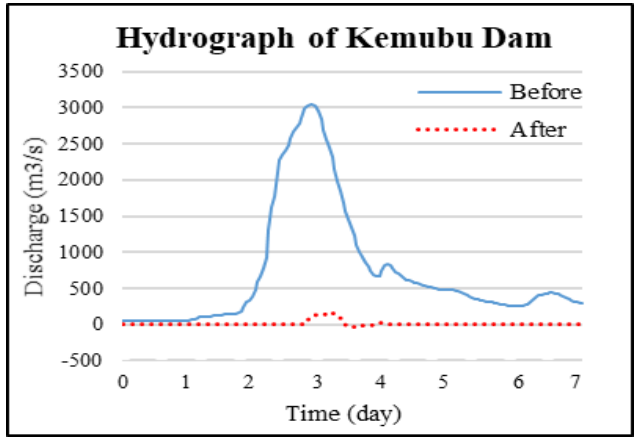

Fig. 8. Discharge hydrograph before and after the development of the proposed Kemubu dam

\subsection{The Accuracy of The Simulated Flood Depth}

From the comparison of the flood depth from model and flood marks depth, the average of the depth difference was about $3.85 \mathrm{~m}$. The average depth difference of this study may be higher because this study only validates with 16 locations from two different references. Even so, the percentage accuracy can be enhanced by using abundant locations to be validated. Figure 9 shows the flood depth graph of 2014 flood in Kuala Krai that has been plotted. It showed the pattern of the simulated flood depth and the flood marks depth from field survey. As can be seen in the plotted graph, the distribution of the flood depth from simulation and flood marks showed the same pattern. However, there is some error may be occurred from the flood model where the calculated RMSE was 4.63. The flood depth difference and the accuracy of 16 locations are shown in Table 2. Further, Figure 10 shows the map of the locations that have been validating in this study.

Table 2 Validation of Flood Depth Against Floodmarks Depth for 2014 Flood Event

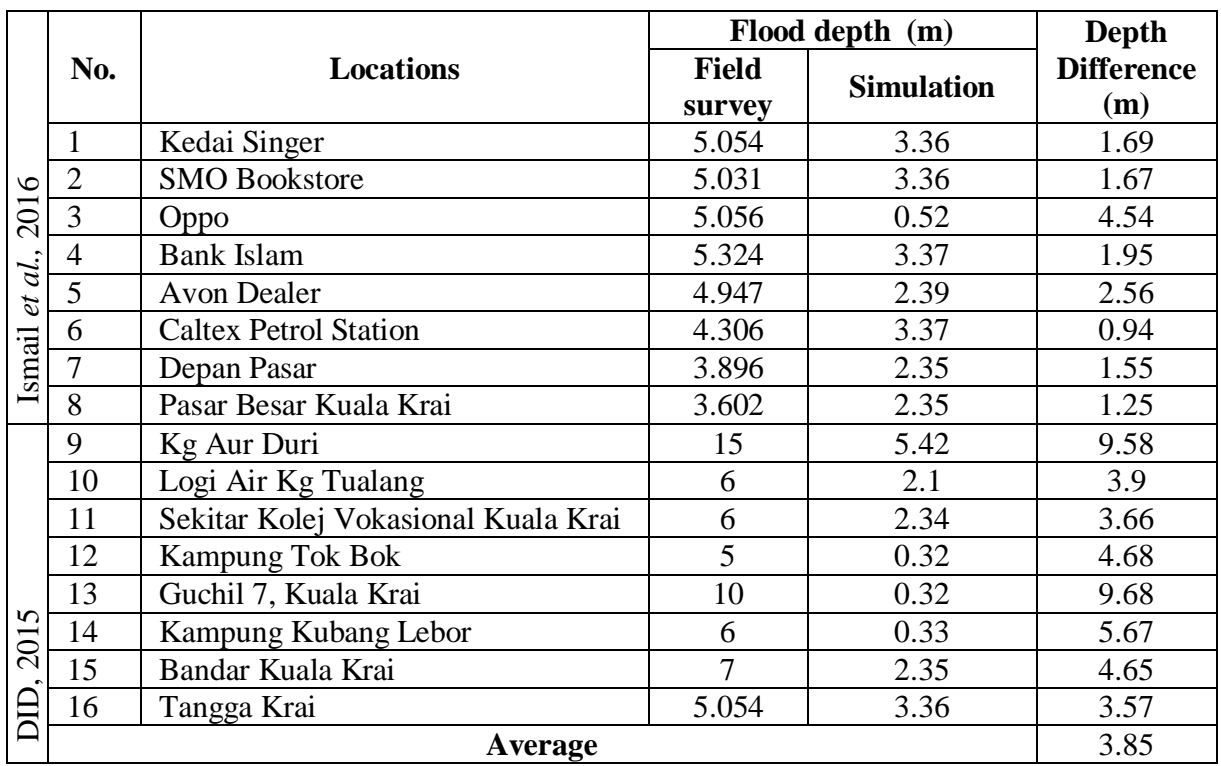




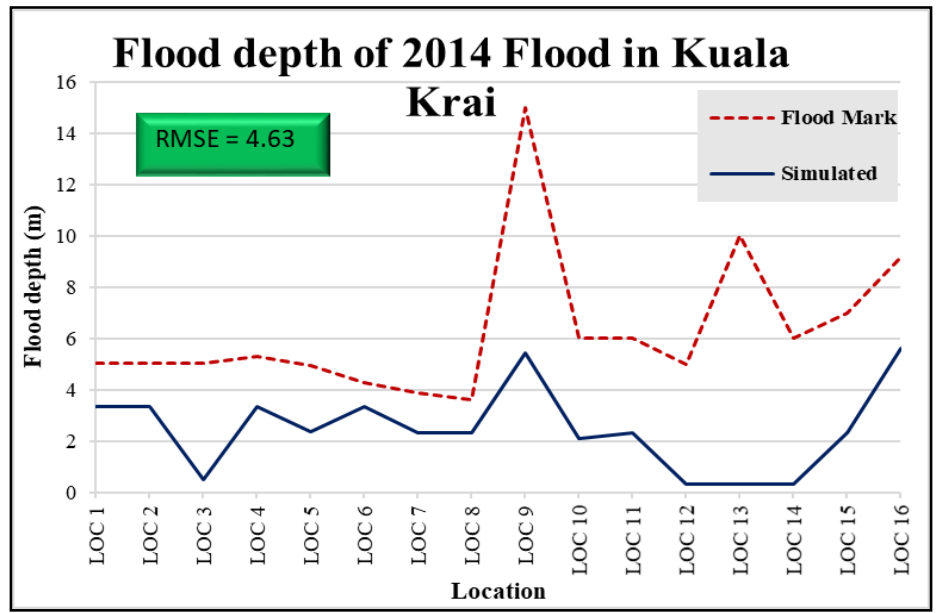

Fig. 9. The pattern of the simulated flood depth and the flood marks depth from field survey

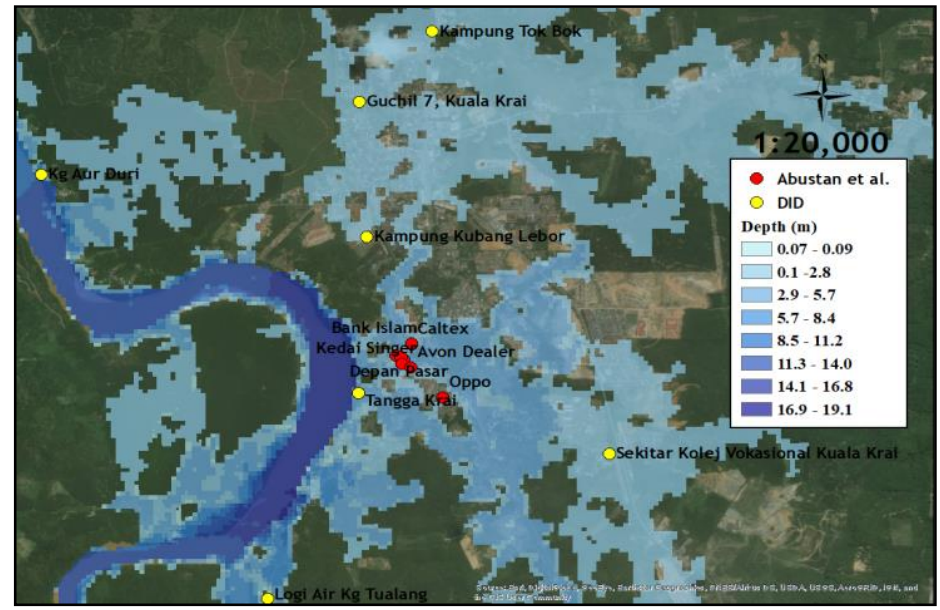

Fig 10. The map of location for validate flood depth

\section{Conclusion}

This study reveals that the integration of hydrodynamic modelling together with Remote Sensing and Geographical Information System (GIS) has been significant tools to assess the implementation of the structural approach such as dam for flood mitigation. From the validations of the simulated flood depth against flood depth of 16 locations, it showed that the accuracy of study can be improved with the presence of the abundant of location observed. Nevertheless, the results obtained from the hydrodynamic modelling at Kuala Krai with the proposed dams showed that no flood has occurred downstream. This result, however, should be viewed with more aspects taken into consideration since the flood simulation has been modelled with simplification only by raising the elevation of the DTM surface model. Therefore, it can be said that the proposed dams are beneficial and capable of reducing the flood hazard in Kelantan. This study suggests that the proposed dam should be modelled with proper plans and detailed specifications on how the dam operates, particularly for flood mitigation even during drought session. 
The authors would like to thank the Department of Irrigation and Drainage, Malaysia for providing various data sets for this research. We also thank and acknowledge the Universiti Teknologi Malaysia and Ministry of Higher Education of Malaysia for their financial supports on the research grant Vot Number Q.J130000.2527.11H52.

\section{References}

1. S. F. Maruti, S. Amerudin, W. H. W. Kadir, Z. M. Yusof (2018). A hydrodynamic modelling of proposed dams in reducing flood hazard in Kelantan Catchment. IOP Conf. Series: Earth and Environmental Science, 140 (2018), 1-8.

2. W. H. Azad, L. M. Sidek, H. Basri, C. M. Fai, S. Saidin, Hassan, (2016). 2Dimensional Hydrodynamic Flood Routing Analysis on Flood Forecasting Modelling for Kelantan River Basin. MATEC Web of Conferences, 87, 01016.

3. A. Azlee, (2015, Jan 5). Worst floods in Kelantan, confirms NSC, Malaymail Online. Retrieved from http://www.themalaymailonline.com/malaysia/article/worst-floods-inkelantan-confirms-nsc

4. N. E. Alias, H. Mohamad, W. Y. Chin, Z. Yusop, Rainfall Analysis of The Kelantan Big Yellow Flood 2014 Journal Teknologi (Sciences and Engineering), 78: 9-4 (2016), 83-90, (2016).

5. S. F. Maruti, S. Amerudin, W. H. W. Kadir, M. Z. A. Rahman, Z. M., Yusof, A. Ariffin, T. T. Huey, Hydrodynamic Modelling of A Proposed Lebir And Galas Dam For Flood Hazard Analysis. Malaysian Journal of Civil Engineering, 201628 Special Issue 3 (2016), 223-229 (2016)

6. M. Z. A. Rahman, T. T. Huey, S. Ameruddin, Z. M. Yusof, W. H. W. Kadir, N. Alias, M.G. Hashim, A.W. Rasib, A.R.M. Yusoff, H.M. Daud, S.F. Maruti, Jurnal Teknologi, 72:1(2015), 1-6.

7. I. Abustan, M. R. Rozainy, M. A. Zainol, N. A. Rahman, C. W. Kang, M. S. H. Abustan, N. b. Wahib, M.A.A. Kadir, C.K. Lin, K. Takara (2016). Flood Hazard Map Utilizing Public Domain Inundation Hydrological (RRI) And Hydraulic (HECRAS) Model And GIS. In Z. Yusop \& N. Mahpof (Eds.), Laporan Akhir Persidangan Kajian Bencana Banjir 2014.

8. Department of Irrigation and Drainage Malaysia (DID). (2016). Flood Mark Retrieve from Collector Apps.

9. UPEN (Unit Perancang Ekonomi Negeri). (1989). Laporan Kajian Tebatan Banjir Menyeluruh Bagi Kawasan Limbangan Sungai Kelantan (Draf Laporan Akhir). Unit Perancang Ekonomi Negeri, Pejabat Setiausaha Kerajaan Negeri Kelantan, Kota Bharu, Kelantan, 39.

10. Chow, V. T. (1959). Open-channel hydraulics. New York: McGraw-Hill.

11. Gilles, D., and Moore, M. (2010). Review of Hydraulic Flood Modeling Software used in Belgium, The Netherlands, and The United Kingdom. International Perspectives in Water Resource Management, IIHR Hydroscience \& Engineering, University of Iowa, 17. 